\title{
TEKNOLOGI HIDROPONIK SISTEM SUMBU PADA PRODUKSI SELADA LOLLO ROSSA (Lactuca sativa L.) DENGAN PENAMBAHAN $\mathrm{CaCl}_{2}$ SEBAGAI NUTRISI HIDROPONIK

\author{
Hydroponic Technology of Wick System on Lollo Rossa Production (Lactuca sativa L.) with \\ Addition of $\mathrm{Cacl}_{2}$ as a Hydroponic Nutrition
}

\author{
Siti Kamalia $^{1) *}$, Parawita Dewanti ${ }^{1)}$, Raden Soedradjad ${ }^{1)}$ \\ ${ }^{1)}$ Program Studi Agroteknologi, Fakultas Pertanian, Universitas Jember \\ Jalan Kalimantan 37, Kampus Tegal Boto, Jember 68121 \\ *E-mail: parawita.faperta@unej.ac.id
}

\begin{abstract}
Calcium in one of the important minerals that are needed by human body as much as $1200 \mathrm{mg}$ calciums/ day/ person. Every day humans consume calcium as much as $254 \mathrm{mg} /$ day/ person and it causes people suffering ostheoporosis and other growth disorders. Therefore human needs to consume the source of calcium, one of them is vegetables. Vegetables in one of the source of calcium that is cheap, obtainable and consumable. Lettuce (Lactuca sativa L.) is one of the vegetable with high caclsium but development of lettuce cultivation is still limited. The efford to increase the quantity and quality of lettuce production can be done with hydroponics technology. Hydroponics technology enables efficient lettuce cultivation. The innovation adding of $\mathrm{CaCl}_{2}$ concentration in hydroponic nutrients is expected to increase the lettuce production. The purpose of this research was to determine the concentration of $\mathrm{CaCl}_{2}$ on the hydroponic nutrients of wick system on the production of Lollo Rossa lettuce (Lactuca sativa L.). The research was conducted at the Green House, Faculty of Agriculture, University of Jember, started in August to Noverber 2016. The research used Completely Randomized Design (CRD) with single factor, which was concentration of CaCl2 on the hydroponic nutrients $(C)$ and it be combined with Lollo Rossa varieties of lettuce (Lactuca sativa L.) (S) with three replications. The best concentration of $\mathrm{CaCl}_{2}$ for Lollo Rossa production was 650 ppm
\end{abstract}

Keywords: Lettuce, Hydroponic, Calcium, $\mathrm{CaCl}_{2}$

\section{PENDAHULUAN}

Kalsium merupakan salah satu unsur mineral yang penting dan diperlukan oleh tubuh manusia. Menurut Kuntz (2003) sekitar $1,5-2 \%$ dari berat badan orang dewasa terdiri dari kalsium. Rata-rata asupan kalsium masyarakat Indonesia hanya berkisar $254 \mathrm{mg} / \mathrm{hari} /$ orang sedangkan standar internasional anjuran kecukupan kalsium pada usia 11-24 tahun tubuh manusia memerlukan kalsium sebanyak $1200 \mathrm{mg} /$ hari/orang. Bahaya kekurangan kalsium diantaranya yaitu dapat menimbulkan gangguan pertumbuhan, osteoporosis, rakhitis serta hipertensi dan kanker kolorektal (Centeno et al., 2009).

Sayuran merupakan salah satu sumber kalsium yang mudah didapat, murah, serta dapat dikonsumsi langsung maupun setelah diolah. Selain itu jika dibandingkan dengan sumber kalsium yang lainnya, kandungan kalsium yang terdapat di dalam sayuran cukup tinggi yaitu sekitar 48 - $150 \mathrm{mg} / 100$ gram. Berdasarkan data BPS (2012) terjadi peningkatan produksi sayuran pada tahun 2011 sebesar 695,471 ton dibandingkan tahun sebelumnya. Perkembangan produksi sayuran di Jawa Timur tahun 2012 sebesar 1.576.423 ton, 1.534.641 ton di tahun 2013, dan di tahun 2014 produksi sebesar 1.649.310 ton, serta 1.543.849 ton pada tahun 2015 (Badan Pusat Statistik, 2016). Adanya peningkatan produksi tersebut 
merupakan salah satu bentuk pemenuhan kebutuhan konsumsi sayur nasional.

Peningkatan produksi sayuran perlu didukung dengan berbagai usaha, salah satunya yaitu ekstensifikasi dengan pemanfaatan lahan non pertanian yang semakin meningkat serta dengan intensifikasi pertanian. Berdasarkan data perkembangan kesesuaian lahan pertanian di Jawa Timur, luasan lahan non pertanian tahun 2012 seluas $923.471 \mathrm{Ha}$, tahun 2013 seluas 1.041.693 Ha, dan tahun 2014 seluas 1.148.466 Ha (Badan Pusat Statistik, 2016). Pemanfaatan lahan non pertanian dapat didukung dengan intensifikasi pertanian salah satunya yaitu teknologi hidroponik. Siregar et al. (2015) menyatakan teknologi hidroponik adalah inovasi dalam budidaya tanaman tanpa media tanah namum memanfaatkan nutrisi, air, serta bahan yang porus sebagai media tanam. Vidiyanto et al. (2013) teknologi hidroponik dapat meminimalisir kondisi lingkungan non ideal bagi tanaman.

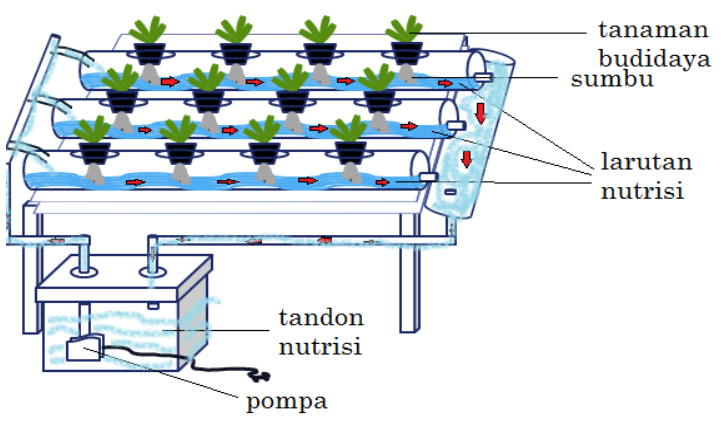

Gambar 1. Desain instalasi hidroponik sistem sumbu tersirkulasi

Salah satu teknik hidroponik yang dapat digunakan yaitu teknologi hidroponik sistem sumbu yang tersirkulasi (Gambar 1). Hidroponik sumbu (wicks) adalah salah satu metode hidroponik yang sederhana dengan menggunakan sumbu sebagai penghubung antara nutrisi dan bagian perakaran pada media tanam. Salah satu kelemahan hidroponik sistem sumbu yaitu larutan nutrisi tidak tersirkulasi sehingga rawan ditumbuhi lumut, pertumbuhan tanaman sedikit lebih lambat. Hal ini dapat diatasi dengan mengkombinasikannya dengan hidroponik sistem sumbu dengan NFT.

Pemanfaatan hidroponik sistem sumbu tersirkulasi memiliki kelebihan secara khusus yaitu kombinasi kedua sistem hidroponik ini yaitu larutan nutrisi dapat tersirkulasi serta volume larutan hara yang dibutuhkan lebih rendah. Kelebihan lain dari sistem ini yaitu larutan nutrisi dalam keadaan tersedia, sirkulasi mencegah lumut, bersih dan mudah dikontrol, tanaman tumbuh dengan optimal, umur panen menjadi lebih singkat dan penggunaan nutrisi yang efisien. Namun kekurangan sistem tersebut yaitu biaya investasi cukup mahal.

Salah satu tanaman yang dapat dibudidayakan secara hidroponik yaitu selada. Selain itu selada (Lactuca sativa L.) merupakan salah satu sayuran yang memiliki kandungan kalsium cukup tinggi yaitu sebesar $56 \mathrm{mg} / 100$ gram jika dibandingkan dengan sayuran lainnya (International Osteoporosis Foundation, 2015). Selada dapat dikonsumsi sebagai salah satu pilihan terbaik untuk mencukupi kebutuhan kalsium harian. Pemanfaatan teknologi hidroponik diharapkan mampu memperbaiki produksi selada (Lingga, 2002). Adanya pemanfaatan teknologi hidroponik diharapkan mampu meningkatkan kandungan kalsium secara efisien didukung dengan adanya pemenuhan nutrisi yang sesuai bagi tanaman disertai dengan penambahan kalsium secara ekternal ke dalam nutrisi hidroponik yang digunakan. Tanaman selada akan menunjukkan respon pertumbuhan yang baik pada konsentrasi 250-320 ppm $(400 \mu \mathrm{S} / \mathrm{cm}-500 \mu \mathrm{S} / \mathrm{cm})$ selama masa pembibitan. Rata-rata tanaman selada memiliki tingkat EC maksimal pada kisaran 2.0-3.0 $\mathrm{mS} / \mathrm{cm}$ (Siregar et al., 2015). 
Kalsium klorida yang ditambahkan juga berkonstribusi untuk memperkokok jaringan tanaman sehingga pemberian $\mathrm{CaCl}_{2}$ diharapkan mampu meningkatkan kandungan $\mathrm{Ca}$ serta mampu memberikan terhadap kerenyahan selada. Penambahan kandungan kalsium dalam selada tersebut diharapkan mampu memenuhi kebutuhan manusia dengan adanya penambahan unsur Ca pada nutrisi hidroponik. Winarno (1986) menyatakan bahwa penambahan $\mathrm{CaCl}_{2}$ dapat berfungsi sebagai bahan pengeras tekstur sebagai akibat dari terbentuknya ikatan antara kalsium dengan pektat. Adanya ikatan tersebut akan menghasilkan Ca-pektat yang memiliki fungsi untuk memperkokoh jaringan pada tanaman. Penelitian ini bertujuan unuk mengetahui konsentrasi $\mathrm{CaCl}_{2}$ pada nutrisi hidroponik sistem sumbu terhadap produksi selada Lollo Rossa (Lactuca sativa L.)

\section{BAHAN DAN METODE}

\section{Alat dan Bahan}

Alat yang digunakan di antaranya yaitu pompa air, selang, perangkat hidroponik, sprayer, TDS meter, $\mathrm{pH}$ meter, timbangan analitik, gelas ukur, alat tulis. Bahan yang digunakan dalam penelitian di antaranya yaitu benih selada varietas Lollo Rossa, rockwool, netpot, sumbu, air, nutrisi hidroponik $\mathrm{AB}$ mix yang mengandung senyawa $\mathrm{Ca}\left(\mathrm{NO}_{3}\right)_{2}, \quad \mathrm{KNO}_{3}, \quad \mathrm{Fe}-\mathrm{EDTA}$, $\mathrm{KH}_{2} \mathrm{PO}_{4}, \quad\left(\mathrm{NH}_{4}\right)_{2} \mathrm{SO}_{4}, \quad \mathrm{~K}_{2} \mathrm{SO}_{4}, \quad \mathrm{MgSO}_{4}$, $\mathrm{CuSO}_{4}, \mathrm{ZnSO}_{4}, \mathrm{H}_{3} \mathrm{Bo}_{3}, \mathrm{MnSO}_{4}$, dan $\mathrm{MoO}_{4}$, $\mathrm{CaCl}_{2}$.

\section{Tahapan Penelitian.}

\section{Pembibitan}

Pembibitan varietas tanaman selada (Lactuca sativa L.) dilakukan dengan cara menyemaikan benih tanaman selada (Lactuca sativa L.) tersebut pada Rockwool. Benih yang telah disemai tersebut dirawat sampai berumur 10 hari setelah semai dan berdaun 3-4 helai dapat dipindah tanam ke instalasi.
Pembuatan larutan nutrisi $A B$ mix dan $\mathrm{CaCl}_{2}$

Proses pembuatan nutrisi stok A dan stok B dilakukan dengan melarutkan nutrisi stok A ke dalam 5 liter air diikuti dengan melarutkan nutrisi stok $\mathrm{B}$ ke dalam 5 liter air. Pembuatan stok $\mathrm{CaCl}_{2}$ dilakukan dengan melarutkan $\mathrm{CaCl}_{2} \mathrm{ke}$ dalam 1 liter.

\section{Pemindahan bibit dan penanaman}

Melakukan pengisian air ke dalam masing-masing instalasi hidroponik kemudian menambahkan nutrisi $\mathrm{AB}$ mix dan stok $\mathrm{CaCl}_{2}$ dengan konsentrasi yang berbeda ke dalam masing-masing instalasi. Memindahkan bibit ke dalam netpot beserta sumbu yang telah disediakan. Kemudian menempatkan dan menanamnya pada instalasi hidroponik yang telah teraliri larutan nutrisi.

\section{Aplikasi larutan nutrisi}

Penambahan larutan nutrisi dilakukan setiap tiga hari sekali atau setiap terjadi penurunan konsentrasi larutan nutrisi setelah dilakukan pengecekan konsentrasi setiap hari.

\section{Pemeliharaan}

Proses perawatan yang dilakukan selama proses pembudidayaan tersebut meliputi penyulaman, peggantian larutan nutrisi, pemupukan, serta pengendalian hama dan penyakit secara manual.

\section{Pemanenan}

Pemanenan selada dapat dilakukan setelah tanaman berumur 5 minggu setelah tanam. Kriteria panen untuk tanaman selada yaitu sudah memiliki ukuran yang cukup besar namun belum berbunga (Bautista dan Cadiz, 1986).

\section{Rancangan Penelitian.}

Penelitian ini dilakukan menggunakan metode Rancangan Acak Lengkap (RAL) yang terdiri dari satu faktor perlakuan dan diaplikasikan pada selada varietas Selada Lollo Rossa, dan 
diulang sebanyak 3 kali. Faktor perlakuan tersebut yaitu penambahan konsentrasi $\mathrm{CaCl}_{2}$ pada nutrisi (C) terdiri atas 4 taraf, yaitu: $\mathrm{C} 0$ (penambahan $\mathrm{CaCl}_{2} 0$ ppm), $\mathrm{C} 1$ (penambahan $\mathrm{CaCl}_{2} 550 \mathrm{ppm}$ ), $\mathrm{C} 2$ (penambahan $\mathrm{CaCl}_{2} 650 \mathrm{ppm}$ ), dan $\mathrm{C} 3$ (penambahan $\mathrm{CaCl}_{2} 750 \mathrm{ppm}$ ).

\section{Variabel pengamatan}

Variabel pengamatan meliputi tinggi tanaman, jumlah daun, volume daun, berat segar, laju pertumbuhan tanaman, daya simpan pada suhu $27^{\circ} \mathrm{C}$ dan $4^{\circ} \mathrm{C}$, tingkat kerenyahan, dan kadar kalsium.

\section{HASIL DAN PEMBAHASAN}

Hasil analisis sidik ragam dari semua parameter pengamatan disajikan pada Tabel 1.

Tabel 1. Rangkuman hasil sidik ragam semua parameter pengamatan

\begin{tabular}{lc}
\hline \multicolumn{1}{c}{ Variabel Pengamatan } & $\begin{array}{c}\text { F-hitung Selada } \\
\text { Lollo Rossa }\end{array}$ \\
\hline Tinggi Tanaman (cm) & $0,51 \mathrm{tn}$ \\
Jumlah Daun (helai) & $1,71 \mathrm{tn}$ \\
Volume Daun (ml) & $7,51 *$ \\
Berat Segar (gr) & $11,92^{* *}$ \\
Laju Pertumbuhan & $97,35^{* *}$ \\
Tanaman (gr/hari) & \\
\hline
\end{tabular}

Keterangan: $* *=$ berbeda sangat nyata,

$*$ = berbeda nyata,

tn $=$ berbeda tidak nyata

Berdasarkan Tabel 1 perlakuan penambahan $\mathrm{CaCl}_{2}$ pada Selada varietas Lollo Rossa (S2) memberikan pengaruh berbeda sangat nyata pada parameter berat segar dan laju pertumbuhan tanaman, memberikan pengaruh nyata terhadap parameter volume daun, serta memberikan pengaruh yang tidak berbeda nyata pada parameter tinggi tanaman, jumlah daun. Aplikasi $\mathrm{CaCl}_{2}$ yang berpengaruh nyata terhadap variabel volume daun, berat segar, dan laju pertumbuhan tanaman selada Lollo
Rossa dapat dilihat pada grafik-grafik dibawah ini.

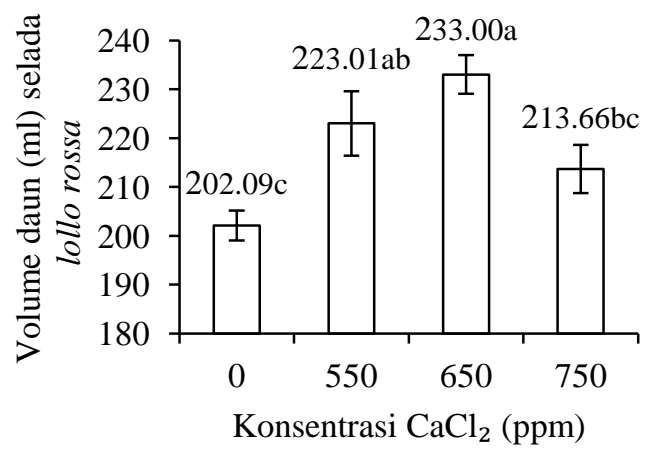

Gambar 2. Pengaruh penambahan $\mathrm{CaCl}_{2}$ pada volume daun $(\mathrm{ml})$ varietas selada Lollo Rossa

Keterangan: Angka yang diikuti oleh huruf yang sama pada grafik batang dengan gambar yang sama menunjukkan tidak berbeda nyata menurut uji DMRT pada tingkat kepercayaan 95\%

Kadar Ca jaringan yang semakin tinggi akan meningkatakan fungsi kalsium bagi tumbuhan diantaranya yaitu mempengaruhi proses pembelahan sel serta menguatkan dinding sel. Berdasarkan hasil yang ditunjukkan oleh Gambar 2. diketahui bahwa, selada Lollo Rossa menunjukkan nilai volume daun terbaik dengan konsentrasi $\mathrm{CaCl}_{2}$ sebanyak $650 \mathrm{ppm}(\mathrm{C} 2 \mathrm{~S} 2)$ yaitu sebesar yaitu $233 \mathrm{ml}$. 


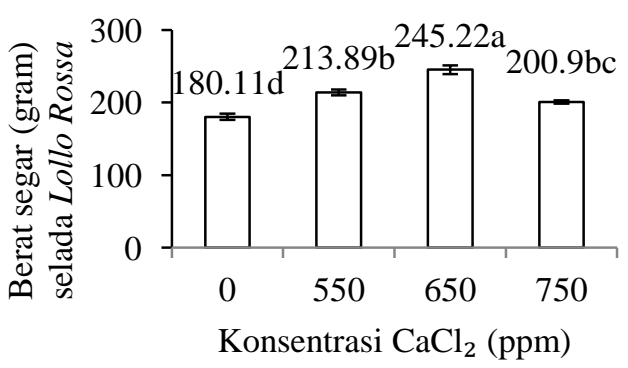

Gambar 3. Pengaruh penambahan $\mathrm{CaCl} 2$ berat segar (gram) varietas selada Lollo Rossa

Keterangan : Angka yang diikuti oleh huruf yang sama pada grafik batang dengan gambar yang sama menunjukkan tidak berbeda nyata menurut uji DMRT pada tingkat kepercayaan $95 \%$

Daun yang dihitung merupakan daun yang telah terbuka sempurna. Berdasarkan Gambar 3 diketahui bahwa konsentrasi $\mathrm{CaCl}_{2} 650$ ppm (C2S2) menunjukkan hasil berat segar terbaik pada selada Lollo Rossa yaitu sebesar 245,22 gram. Penanaman selada secara konvensional mampu menghasilkan 3-8 ton/ha (Grubben dan Sukprakarn, 1994). Menurut Resh (2004) potensi hasil yang dapat diperoleh melalui penanaman tanpa media tanah yaitu sekitar 10 ton/ ha. Potensi hasil berat segar tanaman selada yang mampu mencapai 350 gram dengan penambahan pupuk organik. Hasil penelitian yang telah dilakukan menunjukkan bahwa rata-rata berat segar terbaik pada varietas Lollo Rossa yaitu sebesar 245,22 gram (Gambar 3). Selada yang dihasilkan pada penelitiaan ini belum mencapai hasil yang maksimal dapat dikarenakan faktor musim ketika penelitian dilakukan. Penelitian ini dilakukan saat masuk musim penghujan dengan intensitas penyinaran yang tidak optimal dibandingkan intensitas cahaya matahari ketika musim kemarau. Menurut Ginting (2010) rata-rata intensitas cahaya matahari pada musim kemarau sebesar 45.000 lux sedangkan rata-rata intensitas cahaya matahari ketika musim penghujan hanya sebesar 10.500 lux. Tanaman selada memerlukan intensitas cahaya matahari sebesar 2151,78 - 4305,56 lux (Rukmana, 1994). Ketika penelitian dilaksanaan rata-rata intensitas penyinaran di dalam rumah kaca selama pagi hingga sore hari berkisar 9861 lux .

Intensitas cahaya tersebut masih tergolong rendah dibanding standar intensitas cahaya yang dibuytuhkan tanaman sebesar 20.000 lux (Landis et al., 2013). Intensitas cahaya matahari dapat memberikan pengaruh bagi pertumbuhan tanaman melalui proses transpirasi (Myrna dan Lestari, 2010). Intensitas cahaya yang rendah dapat menyebabkan proses transpirasi menurun. Menurut Pamujiningtyas dan Susila (2005) intensitas cahaya matahari yang rendah karena adanya naungan menyebabkan stomata semakin sedikit sehingga energi matahari yang diserap semakin rendah, difusi $\mathrm{CO}_{2}$, dan transpirasi menurun. Hal ini mengakibatkan penurunan absorbsi unsur hara dan air. Rendahnya intensitas cahaya tersebut dapat menjadi salah satu faktor yang menyebabkan berat segar selada tidak mampu mencapai potensi berat segar optimal.

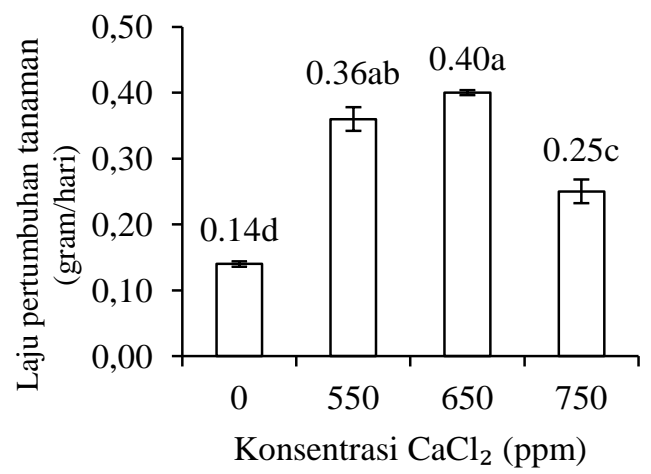

Gambar 4. Pengaruh penambahan $\mathrm{CaCl}_{2}$ pada Laju pertumbuhan tanaman (gram/hari) varietas selada Lollo Rossa

Keterangan : Angka yang diikuti oleh huruf yang sama pada grafik batang dengan gambar yang sama menunjukkan tidak berbeda nyata menurut uji DMRT pada tingkat kepercayaan $95 \%$ 
Gambar 4 menunjukkan bahwa respon yang ditunjukkan masing-masing varietas selada berbeda tiap aplikasi $\mathrm{CaCl}_{2}$ yang diberikan. Laju pertumbuuhan terbaik diikuti dengan hasil produksi yang optimal. Varietas Lollo Rossa menunjukkan hasil terbaik pada perlakuan C2S2 (aplikasi $\mathrm{CaCl}_{2} 650$ ppm) dengan nilai laju pertumbuhan rata-rata sebesar $0,40 \mathrm{~g} /$ hari. Semakin tinggi penambahan $\mathrm{CaCl}_{2}$ pada nutrisi maka laju pertumbuhan tanaman kedua varietas selada tersebut cenderung menurun.

Kalsium merupakan salah satu unsur
hara yang dapat mempengaruhi pemanjangan sel. Hal ini dapat dikarenakan keberadaan kalsium berkaitan dengan hormon auksin yang terdapat pada tanaman. Auksin akan mempengaruhi pelenturan dinding sel tanaman. Keberadaan auksin akan memacu protein tertentu sehingga ion $\mathrm{H}^{+}$akan terpompa ke dalam diding sel tanaman. Ion hidrogen tersebut akan mengaktifkan enzim tertentu sehingga menyebabkan terputusnya ikatan silang hidrogen dengan rantai molekul selulosa penyusun dinding sel. Adanya air yang masuk secara osmosis akan menyebabkan sel tumbuhan memanjang. Sel akan terus tumbuh dengan mensintesis kembali material dinding sel dan sitoplasma setelah proses pemjangan sel. Sehingga pemanjangan sel tanaman juga diikuti dengan adanya pembentukan dinding sel tanaman. Pemanjangan sel yang diikuti dengan sintesis dinding sel akan memacu pertumbuhan tanaman dengan struktur yang kokoh. Pemberian kalsium ke dalam nutrisi hidroponik dapat mempengaruhi pertumbuhan tinggi tanaman disertai dengan struktur yang tegak.
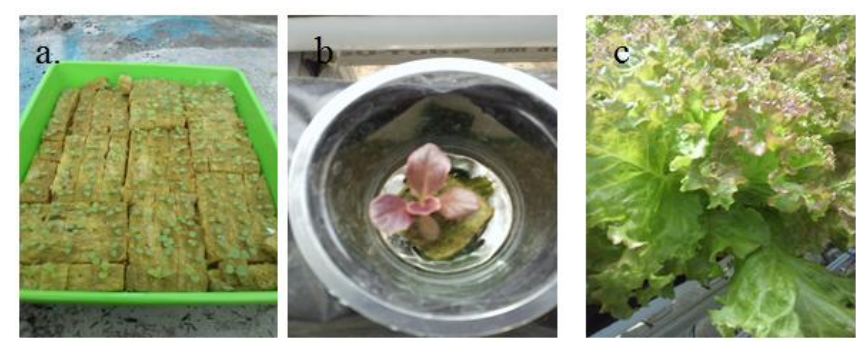

Gambar 5. a). Bibit selada Lollo Rossa umur 5 hari setelah semai, b). Selada Lollo Rossa yang dipindah tanam, c). Selada Lollo Rossa siap panen

Lama pembibitan selada dilakukan selama 10 hari dari waktu semai. Selama masa pembibitan, bibit selada dipelihara dengan cara melakukan penyiraman secara rutin setiap harinya menggunakan larutan nutrisi dengan EC $400 \mu \mathrm{S} / \mathrm{cm}$ $500 \mu \mathrm{S} / \mathrm{cm}$ (Siregar et al., 2015) sehingga menghasilkan bibit selada siap pindah tanam ketika umur 10 hari setelah semai (Gambar 5a). Setelah berumur 10 hari setelah semai maka bibit selada dapat dipindah tanam ke instalasi hidroponik (Gambar 5b). Morfologi selada Lollo Rossa yang tumbuh dengan optimal dan dapat dipanen peda umur 35 hari setelah semai akan memiliki pertumbuhan yang tegak serta ukuran yang cukup besar namun belum berbunga (Bautista dan Cadiz, 1986). Selada Lollo Rossa memiliki morfologi daun dengan tepian yang bergerigi serta warna yang merah serta tinggi mencapai 20-30 cm bahkan lebih (Gambar 5c). 


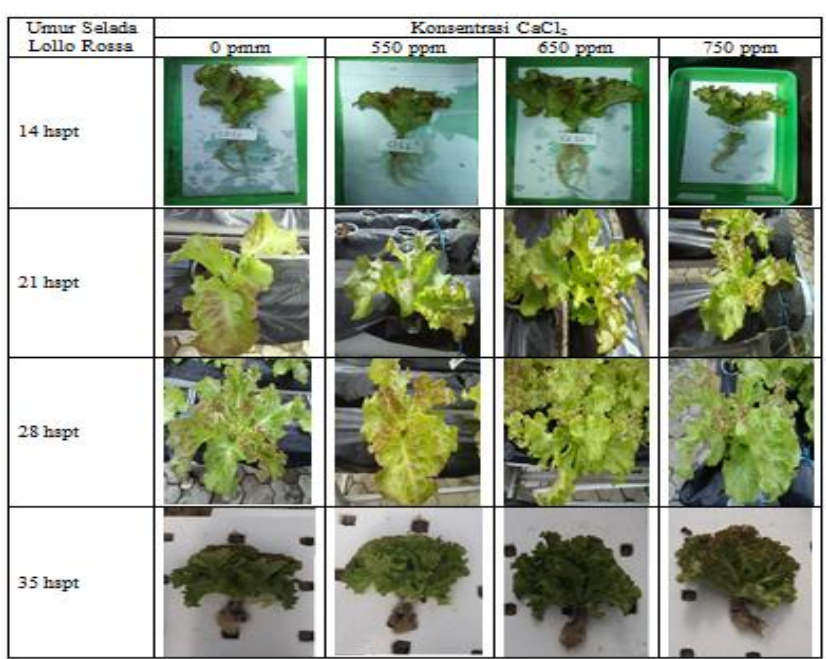

Tabel 2. Pertumbuhan Selada Lollo Rossa pada umur berdeda dengan konsentrasi $\mathrm{CaCl}_{2}$ yang berbeda

$\begin{array}{rrrr}\text { Pertumbuhan } & \text { selada } & \text { Lollo } & \text { Rossa } \\ \text { dengan aplikasi } & \mathrm{CaCl}_{2} & 650 & \mathrm{ppm}\end{array}$
menunjukkan potensi produksi yang baik dibandingkan ketiga perlakuan yang lainnya. Hal tersebut dapat dilihat dari pertumbuhan selada yang ditunjukkan oleh volume daun yang dihasilkan (Tabel 2). Aplikasi $\mathrm{CaCl}_{2}$ hingga konsentrasi $650 \mathrm{ppm}$ menghasilkan pertumbuhan volume daun yang meningkat pada umur 14 sampai dengan umur 35 hari setelah pindah tanam. Volume daun selada pada perlakuan tersebut cenderung lebih baik dibandingkan tiga perlakuan lainnya, namun aplikasi $\mathrm{CaCl}_{2}$ yang lebih besar dari perlakuan optimal akan menurunkan volume daun selada yang dihasilkan.

Budidaya selada dengan hidroponik sistem sumbu tersirkulasi mampu mengoptimalkan pertumbuhan selada. Sirkulasi nutrisi pada instalasi mampu meratakan sebaran nutrisi dalam aliran air untuk semua tanaman. Pemanfaatan sirkulasi nutrisi juga memberikan asupan $\mathrm{O}_{2}$ yang dibutuhkan perakaran tanaman serta menjaga suhu larutan nutrisi tetap sejuk sehingga penyerapan larutan nutrisi tetap optimal.

Kalsium merupakan salah satu unsur hara makro esensial yang diserap tanaman dalam bentuk ion $\mathrm{Ca}^{2+}$. Pada dasarnya, kandungan kalsium dalam sumber air yang digunakan pada penelitian ini sebesar 5 ppm. Kebutuhan kalsium selada dalam budidaya hidroponik yaitu 150-200 ppm (Resh, 2004). Konsentrasi kalsium yang sesuai tanaman selada hidroponik dapat dipenuhi melalui penambahan $\mathrm{CaCl}_{2}$ ke dalam nutrisi. Penambahan $\mathrm{CaCl}_{2}$ sesuai dengan konsentrasi yang diperlukan selada memberi pengaruh terhadap peningkatan produksi selada.

Kandungan kalsium dalam jaringan daun tanaman akan semakin tinggi apabila konsentrasi $\mathrm{Ca}$ yang diaplikasikan ke dalam larutan nutrisi semakin tinggi (Rohmaniyah et al., 2015). Semakin tinggi konsentrasi $\mathrm{CaCl}_{2}$ yang ditambahkan maka produksi cenderung menurun. Penambahan konsentrasi $\mathrm{CaCl}_{2}$ yang sesuai untuk produksi selada Lollo Rossa yaitu 650 ppm, karena produksi yang dihasilkan pada konsentrasi tersebut menunjukkan tinggi tanaman yang optimal.

Menurut Resh (2004) kalsium memiliki peranan dalam struktur sel tanaman (dinding dan membran sel) serta dibutuhkan dalam pembentukan dan pembelahan sel-sel baru yaitu pada benang-benang (spindles) pada pembelahan mitosis. Keberadaan kalsium dapat mempengaruhi pembentukan dinding sel baru pada proses pembelahan sel. Apabila tanaman kekurangan kalsium maka pembelahan sel atau mitosis tidak akan sempurna karena dinding sel baru tidak akan terbentuk sehingga menghasilkan sel-sel multi nukleat. Akibatnya akan memicu devisiensi kalsium pada tanaman.

Konsentrasi $\mathrm{CaCl}_{2}$ lebih besar dari konsentrasi $\mathrm{CaCl}_{2}$ yang sesuai bagi selada Lollo Rossa akan mengakibatkan penurunan produksi baik dari segi volume daun, berat segar maupun laju pertumbuhan tanaman. Aplikasi $\mathrm{CaCl}_{2}$ yang lebih tinggi akan menyebabkan $\mathrm{pH}$ 
media meningkat sehingga $\mathrm{pH}$ media menjadi tinggi. Tingginya $\mathrm{pH}$ media akan mengakibatkan unsur hara mikro $(\mathrm{Zn}, \mathrm{Cu}$, $\mathrm{B}$, Fe, dan $\mathrm{Mn}$ ) menjadi tidak tersedia (Breemer et al., 2015). Aplikasi Ca dalam bentuk $\mathrm{CaCl}_{2}$ dengan konsentrasi lebih tinggi akan menyebabkan hara mikro dalam keadaan tidak tersedia sehingga meski dalam jumlah sedikit dibutuhkan tanaman, kurangnya unsur hara mikro akan mengganggu pertumbuhan tanaman.

\section{KESIMPULAN}

Konsentrasi $\mathrm{CaCl}_{2}$ pada nutrisi hidroponik sistem sumbu sebesar $650 \mathrm{ppm}$ dapat mendukung produksi selada Lollo Rossa (Lactuca sativa L.). Produksi tersebut ditunjukkan oleh volume daun yang dihasilkan.

\section{DAFTAR PUSTAKA}

Centeno, V., de Barboza G. D., Marchionatti, A., Rodriguez, V., dan deTalamoni N. T. 2009. Molecular mechanisms triggered by low calcium diets. Nutr. Res. Rev., 22: 163-174.

Ginting, C. 2010. Analisis pertumbuhan selada (Lactuca sativa) dibudidayakan secara hidroponik pada musim kemarau dan penghujan. Agriplus., 20 (1): 1-8.

Grubben, G. J. H. dan S. Sukprakarn. 1994. Lactuca sativa L. Plant Resourches of South-East Asia Vegetables. Prosea, Bogor.

International Osteoporosis Foundation. 2015. Calcium content of common foods. www.iofbonehealth.org. [Diakses pada 21 Maret 2015].

Kuntz, L.A., 2003. Elemental calcium facts. www.foodproductdesign.com. [Diakses pada 1 Juni 2012].

Landis. M. J., P. Lamey, dan T. Bedforf. 2013. Bayesian analysis of biogeography when the number of areas is large. System Bilogy., 6 (2): 789-804.
Lingga, Pinus. 2002. Hidroponik: BertanamTanpa Tanah. Penebar Swadaya, Jakarta.

Myrna E. F. N. dan A.P. Lestari. 2010. Peningkatan Efisiensi Konversi Energi Matahari pada Pertanaman Kedele Melalui Penanaman Jagung dengan Jarak Tanam Berbeda. Penelitian Universitas Jambi Seri Sains, 12, (2): 49-54.

Pamujiningtyas. B. K. dan A. D. Susila. 2015. "Pengaruh Aplikasi Naungan dan Pupuk Daun terhadap Pertumbuhan dan Produksi Selada (Lactuca sativa Var. Minetto) dalam Teknologi Hidroponik Sistem Terapung (THST)". Skripsi. Departemen Budidaya Pertanian. IPB, Bogor.

Resh, H. 2004. Hydroponic Food Production Sixth Edition. Newconcept, New Jersey.

Rohmaniyah. L. K., D. Indradewa, dan E. T. S. Putra. 2015. Tanggapan tanaman kangkung (Ipomea reptans Poir.), bayam (Amaranthus tricolor L.), dan selada (Lactuca sativa L.) terhadap pengayaan kalsium secara hidroponik. Vegetalika, 4 ( 2 ): 6378.

Rukmana, Rahmat. 1994. Bertanam Selada dan Andewi. Kanisius, Yoyakarta.

Siregar, J., S. Triyono, dan D. Suhandy. 2015. Pengujian beberapa nutrisi hidroponik pada selada (Lactuca sativa L.) dengan teknologi hidroponik sistem terapung (THST) termodifikasi. Teknik Pertanian,4 (2): 65-72.

Vidianto, D. Z., S. Fatimah, dan C. Wasonowati. 2013. Penerapan panjang talang dan jarak tanam dengan sistem hidroponik $\mathrm{nft}$ (Nutrient Film Technique) pada tanaman kailan (Brassica oleraceae var. alboglabra). Agrovigor, 6 (2): 128-135. 
Teknologi Hidroponik Sistem Sumbu pada Produksi Selada..... Jurnal Agroteknologi, Vol. 11 No.01 (2017)

Winarno FG. 2002. Fisiologi Lepas Panen Produk Hortikultura. M-Brio Press, Bogor. 